J. Ginseng Res.

Vol. 32, No. 1, 73-78 (2008)

\title{
Inhibitory Activities of Red Ginseng Acidic Polysaccharide in Platelet Aggregation
}

\author{
Whi Min Lee, S.M. Kamruzzaman, Yong Bum Song*, Jae Youl Cho**, \\ Hwa Jin Park*** and Man Hee Rhee ${ }^{\#}$ \\ College of Veterinary Medicine, Kyungpook National University, Daegu 702-701, Korea \\ *KT \& G Central Research Institute, Yuseong-Ku, Daejeon 305-345, Korea \\ **School of Bioscience and Biotechnology, Kangwon National University, Chuncheon 200-701, Korea \\ ***College of Biomedical Science and Engineering, Inje University, Gimhae, 200-701, Korea
}

(Received February 21, 2008; Accepted March 12, 2008)

\begin{abstract}
Red ginseng acidic polysaccharide (RGAP), isolated from Korean red ginseng (Panax ginseng C.A. Meyer), has been shown to have a variety of biological functions such as immunostimulating and anti-tumor activities. In the present study, we investigated whether RGAP inhibited ligand-induced platelet aggregation. The washed platelet-rich plasma was prepared from male SD rats with successive centrifugation. The platelets $\left(10^{8} / \mathrm{ml}\right)$ were preincubated with 1 $\mathrm{mM}$ of $\mathrm{CaCl}_{2}$ for 2 min either in the presence or in the absence of RGAP $(10 \sim 50 \mu \mathrm{g} / \mathrm{ml})$ and were stimulated with collagen $(2.5 \mu \mathrm{g} / \mathrm{ml})$ and thrombin $(0.1 \mathrm{U} / \mathrm{ml})$. RGAP dose-dependently inhibited thrombin-induced platelet aggregation with $\mathrm{IC}_{50}$ value of $26.2 \pm 2.0 \mu \mathrm{g} / \mathrm{ml}$. In collagen-induced platelet aggregation, RGAP inhibited the reaction with an $\mathrm{IC}_{50}$ value of $31.5 \pm 3.0 \mu \mathrm{g} / \mathrm{ml}$. RGAP potently suppressed the intracellular calcium ion, which was stimulated by thrombin $(0.1 \mathrm{U} /$ $\mathrm{ml}$ ). Among mitogen-activated protein kinase (MAPK) subtypes, the extracellular signal-regulated kinase (ERK) $1 / 2$ and p38 MAPK were analyzed in the present study. RGAP inhibited the phosphorylation of ERK2 and p38 MAPK, which was activated by collagen $(2.5 \mu \mathrm{g} / \mathrm{ml})$. Finally, these results suggested that besides saponin fraction, RGAP take an important role in the preventive effect of Korean red ginseng against cardiovascular disease such as thrombosis and atherosclerosis.
\end{abstract}

Key word : Red Ginseng Acidic Polysaccharide, Platelet aggregation, Thrombin, Collagen, Extracellular signal-regulated Kinase 1/2, p38 Mitogen-activated protein kinase

\section{INTRODUCTION}

Platelets are anucleate, which is produced from cytoplasmic fragmentation of megakaryocytes without genomic DNA $^{1,2)}$. Due to the relatively restriction of protein synthesis, the platelets are known to be a good model system to study intracellular signal transduction in mammalian cells ${ }^{1,3,4)}$. Platelets play an important role both in the hemostatic process and in thrombus formation after an endothelial damage ${ }^{5,6)}$. Once vascular injury occurs, platelets will be activated by endogenous agonists such as ADP and collagen, and adhere to the site of an injury ${ }^{6-8)}$. Upon binding of agonists to their receptor, platelets are activated and the contents of the granules are released.

\footnotetext{
${ }^{\#}$ To whom correspondence should be addressed

(Tel) +82-53-950-5967; (Fax) +82-53-950-5955

(E-mail) rheemh@knu.ac.kr
}

The process of platelet activation is regulated, in part, by level of the second messengers, adenosine 3:5-cyclic monophosphate (cAMP) and guanosine 3:5-cyclic monophosphate (cGMP) ${ }^{9,10)}$. Increase of intracellular cAMP or cGMP levels leads to inhibition of agonist-induced platelet activation-aggregation, adhesion and release of granule contents ${ }^{11)}$. Moreover, adenylate or guanylate cyclase activators and phosphodiesterase inhibitors do synergistically elevate intracellular cAMP or cGMP levels, providing a good rationale for the therapeutic use of these agents alone or in combination with other agents ${ }^{12-14)}$. Cytosolic $\mathrm{Ca}^{2+}$ also plays a critical role in the regulation of various physiological functions, including aggregation and granule secretion of platelets. Stimulation of platelets with different stimuli, such as thrombin, collagen and ADP, results in an increase in the intracellular $\mathrm{Ca}^{2+}$ concentration $\left(\left[\mathrm{Ca}^{2+}\right]_{\mathrm{i}}\right)^{15-17)}$. 
Korean red ginseng (Panax ginseng C.A. Meyer) has been used for more than 2,000 years as a major component of Far East medicine to treat many ailments. It is traditionally believed that the root of Panax ginseng is a panacea. That is, it is considered as a therapeutic agent against almost all diseases and used in the formulation of tonics for several thousand years. Ginseng contains many active components such as ginsenosides, polysaccharides, peptides, fatty acids and mineral oils ${ }^{18)}$. Among these components, ginsenosides are believed to be responsible for most of the pharmacological and immunological activities of ginseng ${ }^{18,19)}$. Although many researchers believe in this hypothesis, non-saponin fractions also play an important role in the biological activities of Korean red ginseng $^{20-22)}$. It is reported that RGAP was isolated from Korean red ginseng and showed immunostimulating activities, including proliferation of spleen cell and nitric oxide production in macrophages ${ }^{23,24)}$. Moreover, RGAP displayed anti-tumor activity in vitro and in vivo ${ }^{22,24)}$. This study was undertaken to determine whether RGAP modulates platelet aggregation, in comparison with ginsenoside $\operatorname{Rg} 3$ that is a known anti-platelet component of red ginseng ${ }^{25}$ ). First the anti-platelet properties of RGAP were investigated using a platelet aggregation assay that was induced by collagen and thrombin. In addition, the mechanism of RGAP's anti-platelet action was evaluated using a downstream signaling assay. It was found that RGAP showed anti-platelet activity, due to the modulation of intracellular downstream components in activated platelets.

\section{MATERIALS \& METHODS}

\section{Materials}

RGAP was obtained from KT \& G Central Research Institute (Daejon, Korea). Thrombin and Fura-2/AM were obtained from Sigma Co (St. Louis, MO). Collagen was procured from the Chronolog Co (Havertown, PA). Antibodies to phospho-ERK and phospho-p38 MAPK were from Cell Signaling (Beverly, MA). All other chemicals were of reagent grade.

\section{Preparation of platelets}

Blood was obtained from male SD rats weighing 200$300 \mathrm{~g}$. Rats were anesthetized with ethyl ether and the blood was collected from the abdominal aorta. The blood was anti-coagulated with acid-citrate-dextrose (ACD, 85 $\mathrm{mM}$ sodium citrate, $71 \mathrm{mM}$ citric acid, $111 \mathrm{mM}$ dextrose, $\mathrm{pH} 6.5$ ), and was centrifuged at $120 \times \mathrm{g}$ for $7 \mathrm{~min}$ in order to achieve platelet-rich plasma. In order to remove residual erythrocytes, the platelet-rich plasma samples were again centrifuged at $40 \times \mathrm{g}$ for $7 \mathrm{~min}$. In order to isolate the platelets, the platelet-rich plasma was centrifuged twice at $300 \times \mathrm{g}$ for $7 \mathrm{~min}$. The platelets of the precipitate were adjusted to the proper number $\left(10^{8} / \mathrm{ml}\right.$ for an aggregation assay with a Tyrode buffer $[137 \mathrm{mM} \mathrm{NaCl}, 12 \mathrm{mM}$ $\mathrm{NaHCO}_{3}, 5.5 \mathrm{mM}$ glucose, $2 \mathrm{mM} \mathrm{KCl}, 1 \mathrm{mM} \mathrm{MgCl}, 0.3$ $\left.\mathrm{mM} \mathrm{Na} 2 \mathrm{HPO}_{4}, \mathrm{pH} 7.4\right]$ ). All steps for platelet preparation were conducted at room temperature, and all experimental procedures and protocols were reviewed and approved by the Ethics Committee of the College of Veterinary Medicine, Kyungpook National University.

\section{Platelet aggregation assay}

Aggregation was monitored by measuring light transmission using an aggregometer (Chronolog Co, Havertown, PA). The washed platelets were pre-incubated at 37 ${ }^{\circ} \mathrm{C}$ for 2 min with either RGAP or vehicles. The reaction mixture was further incubated for $5 \mathrm{~min}$, stirring at 1,200 $\mathrm{rpm}$, and the degree of aggregation was determined. The concentration of the vehicle was kept at less than $0.2 \%$ so as to exclude artificial effects.

\section{Determining the $\left[\mathrm{Ca}^{2+}\right]_{\mathrm{i}}$}

$\left[\mathrm{Ca}^{2+}\right]_{\mathrm{i}}$ was determined with Fura-2/AM, as described earlier ${ }^{26)}$. Briefly, the platelet-rich plasma was incubated with $5 \mu \mathrm{M}$ of fura- $2 / \mathrm{AM}$ for $60 \mathrm{~min}$ at $37^{\circ} \mathrm{C}$. The fura-2loaded washed platelets $\left(10^{8} / \mathrm{ml}\right)$ were pre-incubated for 2 min at $37^{\circ} \mathrm{C}$, with RGAP in the presence of $1 \mathrm{mM}$ of EDTA. Then, the platelets were stimulated with thrombin for $3 \mathrm{~min}$. Fura-2 fluorescence was measured in a spectrofluorometer (F-2500, Hitachi, Japan), with an excitation wavelength that ranged between $340 \mathrm{~nm}$ and $380 \mathrm{~nm}$ altering every 0.5 seconds; the emission wavelength was at $510 \mathrm{~nm}$. Platelets were lysed with $0.1 \%(\mathrm{v} / \mathrm{v})$ Triton X100 to determine the maximum fluorescence; $20 \mathrm{mM}$ Tris $13 \mathrm{mM}$ of EGTA was added to determine the minimum fluorescence.

\section{Immunoblotting}

Platelet extracts were prepared by standard Laemmli $\operatorname{method}^{27)}$. After the platelet aggregation assay, the sample buffer $(0.125 \mathrm{M}$ Tris-HCl, $2 \%$ SDS, $2 \% \beta$-mercaptoethanol, $20 \%$ glycerol, $0.02 \%$ bromophenol blue, $\mathrm{pH} 6.8$, $2 \mathrm{x}$ ) was added and the protein concentration was determined using PRO-MEASURE (iNtRON Biotechnology, Korea). Following centrifugation at $15,000 \times \mathrm{g}$ for $5 \mathrm{~min}$, $60 \mu \mathrm{g}$ of aliquot proteins were resolved by $10 \%$ SDS- 
PAGE. The resolved proteins were blotted onto nitrocellulose membranes in $25 \mathrm{mM}$ Tris ( $\mathrm{pH} 8.5), 0.2 \mathrm{M}$ glycerin, and $20 \%$ methanol at $100 \mathrm{~V}$ for 2 hrs. Blots were blocked for at least $2 \mathrm{hrs}$ with TBS-tween-20 (TBS-T) containing 5\% nonfat dry milk and were then incubated with an appropriate antibody (1:1,000 dilution ratio in a blocking solution). After washing in TBS-T three times, the blot was incubated with a secondary antibody (1:5,000 dilution ratio in a blocking solution) for $2 \mathrm{hrs}$ and antibody-specific proteins were visualized by the ECL detection system (Supex Co. Pohang, Korea), according to the manufacturer's instructions.

\section{Statistical analysis}

The One-way ANOVA method was used to determine the statistical significance of differences. P values of 0.05 or less were considered as statistically significant.

\section{RESULTS AND DISCUSSION}

\section{RGAP inhibits thrombin- and collagen-induced platelet aggregation.}

Thrombin, an agonist of protease-activated receptor (PAR) 1 and PAR3, induced platelet aggregation in a dose-dependent manner (data not shown) and $0.1 \mathrm{U} / \mathrm{ml}$ of thrombin induced complete platelet aggregation (almost $100 \%$ ). Therefore, $0.1 \mathrm{U} / \mathrm{ml}$ of thrombin was used to induce platelet aggregation in following studies. As shown in Fig. 1, RGAP displayed the inhibitory effect on thrombin-induced platelet aggregation in a dose-dependent manner. The $\mathrm{IC}_{50}$ value of RGAP on thrombin-activated platelet aggregation was $26.2 \pm 2.0 \mu \mathrm{g} / \mathrm{ml}$. Concerning the anti-platelet activity of Korean red ginseng, we and others have found that ginsenoside $\mathrm{Rg} 3$ and non-saponin fraction inhibited platelet aggregation ${ }^{25,28)}$. Ginsenoside $\mathrm{Rg} 3$, a standard drug of anti-platelet action, inhibited the platelet aggregation, which was induced by thrombin $(0.1 \mathrm{U} / \mathrm{ml})$, with IC50 value of $27.7 \pm 5.5 \mu \mathrm{M}$. Whether RGAP also modulate collagen-induced platelet aggregation was then investigated (Fig. 2). Collagen, being located in subendothelial tissue, is an agonist of integrin type $\alpha 2 \beta 1$ and glycoprotein (GP) $\mathrm{VI}^{29,30)}$. As expected, RGAP dosedependently inhibited collagen $(2.5 \mu \mathrm{g} / \mathrm{ml})$-induced platelet aggregation with $\mathrm{IC}_{50}$ value of $31.5 \pm 3.0 \mu \mathrm{g} / \mathrm{ml}$. This data suggested that RGAP modulate the intracellular signaling component in the activated platelets, but does not affect the binding between the ligand and its receptor on the plasma membrane. The platelet aggregation is a sequential and complex reaction in response to agonists



Fig. 1. Effects of RGAP on thrombin $(0.1 \mathrm{U} / \mathrm{ml})$-induced platelet aggregation. Dose-response curves of RGAP on thrombininduced platelet aggregation. The platelets were preincubated with $1 \mathrm{mM}$ of $\mathrm{CaCl}_{2}$ at $37^{\circ} \mathrm{C}$ for $2 \mathrm{~min}$ in the presence of either the vehicle or the indicated concentration of RGAP. The platelets were added with $0.1 \mathrm{U} / \mathrm{ml}$ of thrombin and were further incubated for $5 \mathrm{~min}$. The trace was recorded during the incubation time and the degree of platelet aggregation was determined. The data is given as means $\pm \operatorname{SEM}(n=3)$.

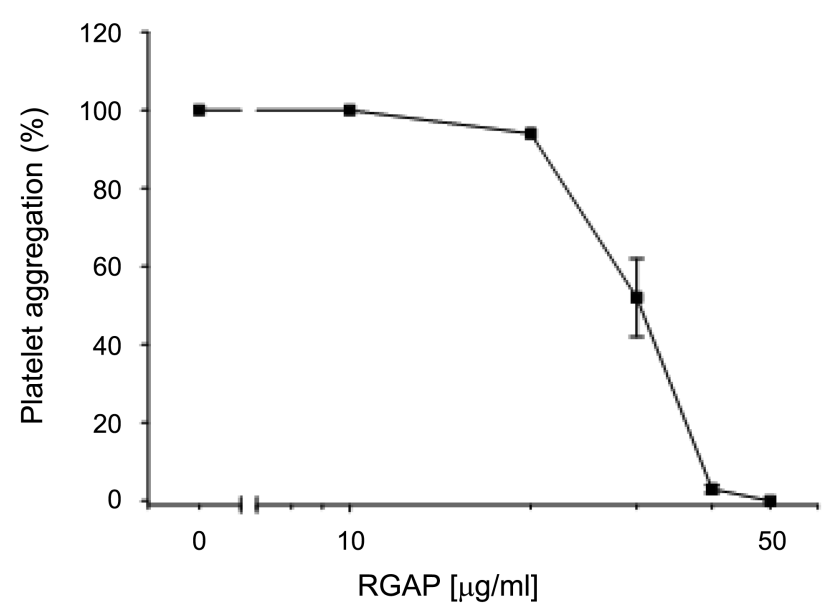

Fig. 2. Effects of RGAP on collagen $(2.5 \mu \mathrm{g} / \mathrm{ml})$-induced platelet aggregation. Dose-response curves of RGAP on collageninduced platelet aggregation. The platelets were preincubated with $1 \mathrm{mM}$ of $\mathrm{CaCl}_{2}$ at $37^{\circ} \mathrm{C}$ for $2 \mathrm{~min}$ in the presence of either the vehicle or the indicated concentration of RGAP. The platelets were combined with $2.5 \mu \mathrm{g} / \mathrm{ml}$ of collagen and were further incubated for 5 min. The trace was recorded during the incubation time and the degree of platelet aggregation was determined. The data is given as means \pm SEM $(n=3)$.

such as thrombin and collagen. Therefore, the accurate action site of RGAP on anti-platelet activity is beyond the 
scope of this study, which remains to be clarified in the future.

The downstream signaling pathway such as $\mathrm{Ca}^{2+}$ and mitogen-activated protein kinase (MAPK) was analyzed next as follows.

RGAP suppresses intracellular calcium concentration $\left(\left[\mathrm{Ca}^{2+}\right]_{\mathrm{i}}\right)$ in thrombin-activated platelets.

Since classical second messengers, $\mathrm{Ca}^{2+}$, play an important role in the process of platelet aggregation, we decided to investigate whether RGAP regulates the $\left[\mathrm{Ca}^{2+}\right]_{\mathrm{i}}$ in thrombin-activated platelets. Using Fura-2/AM-loaded platelets, the $\left[\mathrm{Ca}^{2+}\right]_{i}$ in the presence of either RGAP or vehicle in thrombin-activated platelets was measured. As shown in Fig. 3, thrombin $(0.1 \mathrm{U} / \mathrm{ml})$ significantly increased $\left[\mathrm{Ca}^{2+}\right]_{\mathrm{i}}$, compared to the basal level $(134.7 \pm 30.2 \mathrm{nM}$ vs $1570.7 \pm 691.7 \mathrm{nM})$. RGAP completely suppressed $\left[\mathrm{Ca}^{2+}\right]_{\mathrm{i}}$ at even $10 \mu \mathrm{g} / \mathrm{ml}$ in thrombin-activated platelets. It is well known that $\left[\mathrm{Ca}^{2+}\right]_{\mathrm{i}}$ is an important factor that is involved in platelet aggregation, and is up-regulated by the activation of platelet receptors with thrombin or collagen ${ }^{16,31)}$. The activation of $G$ protein-coupled receptors such as thrombin receptors PAR1 and PAR4, or P2Y ADP receptors, leads to the activation of phospholipase C (PLC)- $\beta$. The resulting inositol-trisphosphate (IP3) generated then binds to IP3 receptors, leading to calcium mobilization from internal stores. Alternatively, collagen binding to

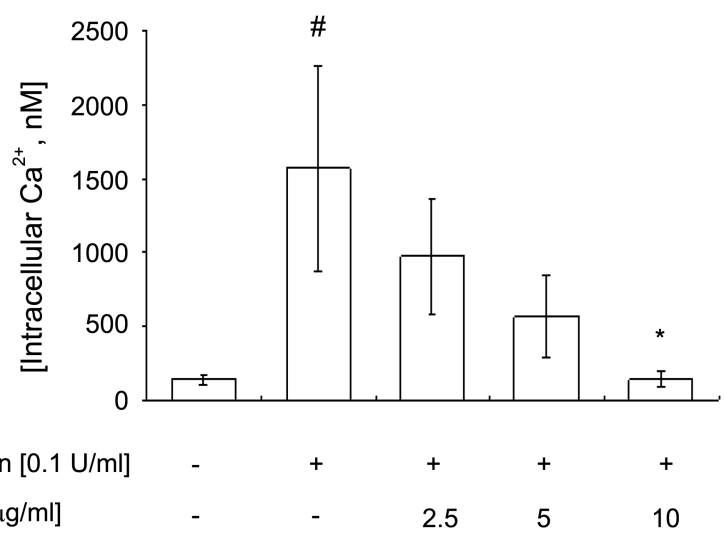

$\begin{array}{llllll}\text { Thrombin }[0.1 \mathrm{U} / \mathrm{ml}] & - & + & + & + & + \\ \operatorname{RGAP}[\mu \mathrm{g} / \mathrm{ml}] & - & - & 2.5 & 5 & 10\end{array}$

Fig. 3. Effects of RGAP on intracellular $\mathrm{Ca}^{2+}$ mobilization induced by thrombin $(0.1 \mathrm{U} / \mathrm{ml})$. Platelets were loaded with Fura2/AM as described in Materials \& Methods. The platelets were pre-incubated in the presence of $1 \mathrm{mM}$ EDTA for $2 \mathrm{~min}$ at $37^{\circ} \mathrm{C}$. The platelets were then stimulated with thrombin $(0.1 \mathrm{U} / \mathrm{ml})$ for $3 \mathrm{~min}$ at $37{ }^{\circ} \mathrm{C}$. Intracellular $\mathrm{Ca}^{2+}$ mobilization was calculated as described in 'Materials \& Methods'. Data are given as mean \pm SEM ( $\mathrm{n}=3$ experiments). $\# \mathrm{P}<0.05$ vs basal, $* \mathrm{P}<0.05$ vs thrombinactivated platelets. glycoprotein VI on the platelet surface increases PLC activity through the phosphorylation of $\mathrm{PLC}_{\gamma}-2$, which also stimulates IP3 release from phosphatidylinositol bisphosphate (PIP2). The IP3 generated by stimulation with collagen then binds to IP3 receptors in the secretory granules of human platelets, resulting in calcium mobilization 17,32,33). This up-regulation of intracellular calcium ions stimulates downstream target proteins, leading to the complete platelet aggregation. In the present study, just 10 $\mu \mathrm{g} / \mathrm{ml}$ of RGAP caused the complete recovery of $\left[\mathrm{Ca}^{2+}\right]_{\mathrm{i}}$ to the basal level. This suggested that the inhibitory modulation of RGAP on $\left[\mathrm{Ca}^{2+}\right]_{i}$ is a critical mechanism of its action.

RGAP suppresses the phosphorylation of extracellular signal-regulated protein kinase 2 (ERK2) and p38 mitogen-activated protein kinase (MAPK).

The MAPK family is comprised of ERK1/2, p38 MAPK, and c-Jun N-terminal kinase (JNK), and in the present study, the alteration of ERK1/2 and p38 MAPK was detected. Collagen $(2.5 \mu \mathrm{g} / \mathrm{ml})$ clearly phosphorylated ERK2 and p38 MAPK; RGAP inhibited ERK2 phosphorylation, but had a much less significant effect on p38 MAPK (Fig. 4). It is reported that ERKs are activated after stimulation by collagen and thrombin ${ }^{34,35)}$, and

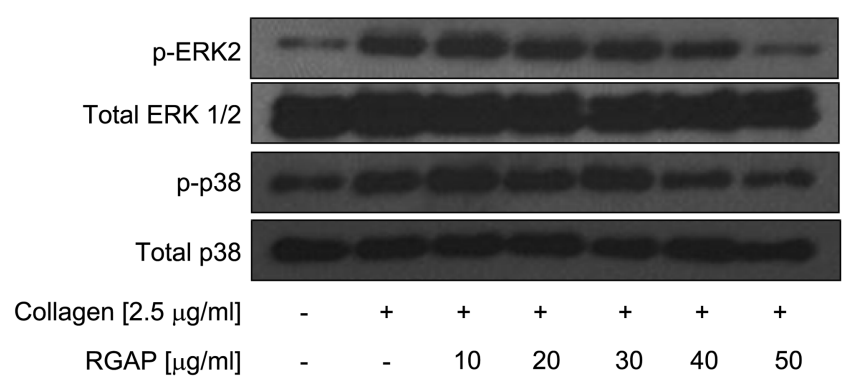

Fig. 4. The effects of RGAP on MAPK phosphorylation in collagen-activated rat platelets. The platelets were preincubated with $1 \mathrm{mM}$ of $\mathrm{CaCl}_{2}$ at $37^{\circ} \mathrm{C}$ for $2 \mathrm{~min}$ in the presence of either the vehicle or the indicated concentration of RGAP. The platelets were combined with $0.1 \mathrm{U} / \mathrm{ml}$ of thrombin and were further incubated for $5 \mathrm{~min}$. The reaction was terminated and sample buffer $(2 \mathrm{x})$ was added. The protein extraction and the protein concentration of platelets are described in the Materials and Methods section. The platelet protein $(60 \mu \mathrm{g})$ was separated with $10 \%$ SDS-PAGE and was blotted onto nitrocellulose membranes. Primary antibody and secondary antibody treatment of the membrane are described in Materials and Methods. Specific bands were visualized with an ECL kit (Supex Co). 
ERK2 activation is involved in collagen-induced platelet aggregation and secretion ${ }^{36)}$. In human platelets, an ERK cascade is required in the activation of store-mediated $\mathrm{Ca}^{2+}$ entry and in the phosphorylation of phospholipase $\mathrm{A} 2^{33,37,38)}$. Regardless of this, the role of MAPK in the process of platelet activation and aggregation is, to some extent, controversial ${ }^{35,37,39)}$. However, this study found that SB203580, a specific inhibitor of p38 MAPK, dosedependently inhibited rat platelet aggregation, which was induced by collagen $(2.5 \mu \mathrm{g} / \mathrm{ml})$, with an $\mathrm{IC}_{50}$ value of $64.0 \pm 5.7 \mu \mathrm{M}$. In addition, $100 \mu \mathrm{M}$ of PD98049, an inhibitor of ERK1/2, completely inhibited the collagen-induced platelet aggregation. In this system, MAPK pathway, such as ERK1/2 and p38 MAPK plays an important role in the platelet aggregation. Therefore, the inhibitory effect of RGAP against ERK2 and p38 MAPK phosphorylation seems to contribute, in part, to its anti-platelet activity in collagen-activated platelets. Both ERK1 and ERK2 are reported to be present in platelets, and this study found that ERK2 was activated following stimulation by collagen.

To summarize, we demonstrated that RGAP has an inhibitory effect on collagen- and thrombin-induced platelet aggregation. RGAP potently suppressed the intracellular calcium ion in thrombin-activated platelets. In addition, among the MAPKs identified in platelets, RGAP inhibited the phosphorylation of p38 MAPK and ERK2 in collagen-activated platelets.

\section{ACKNOWLEDGEMENTS}

This work was supported in part by BK21 (W. M. L.). We thank the KNU proofreading team for critically reading this manuscript.

\section{REFERENCES}

1. Maguire, P. B., Moran, N., Cagney, G. and Fitzgerald, D. J. : Application of proteomics to the study of platelet regulatory mechanisms. Trends Cardiovasc Med. 14, 207-220 (2004).

2. Huo, Y. and Ley, K. : Adhesion molecules and atherogenesis. Acta Physiol Scand. 173, 35-43 (2001).

3. Lindemann, S. and Gawaz, M. : The active platelet: translation and protein synthesis in an anucleate cell. Semin Thromb Hemost. 33, 144-150 (2007).

4. Macaulay, I. C., Carr, P., Gusnanto, A., Ouwehand, W. H., Fitzgerald, D. and Watkins, N. A. : Platelet genomics and proteomics in human health and disease. J Clin Invest. 115, 3370-3377 (2005).
5. Lee, J. J., Jin, Y. R., Lim, Y., Hong, J. T., Kim, T. J., Chung, J. H. and Yun, Y. P. : Antiplatelet activity of carnosol is mediated by the inhibition of TXA2 receptor and cytosolic calcium mobilization. Vascul Pharmacol 45, 148-153 (2006).

6. Huo, Y. and Ley, K. F. : Role of platelets in the development of atherosclerosis. Trends Cardiovasc Med. 14, 18-22 (2004).

7. Corti, R., Farkouh, M. E. and Badimon, J. J. : The vulnerable plaque and acute coronary syndromes. Am J Med 113, 668680 (2002).

8. Ruggeri, Z. M. and Mendolicchio, G. L. : Adhesion mechanisms in platelet function. Circ Res. 100, 1673-1685 (2007).

9. el-Daher, S. S., Eigenthaler, M., Walter, U., Furuichi, T., Miyawaki, A., Mikoshiba, K., Kakkar, V. V. and Authi, K. S. : Distribution and activation of cAMP- and cGMP-dependent protein kinases in highly purified human platelet plasma and intracellular membranes. Thromb Haemost. 76, 10631071 (1996).

10. Jang, E. K., Azzam, J. E., Dickinson, N. T., Davidson, M. M. and Haslam, R. J. : Roles for both cyclic GMP and cyclic AMP in the inhibition of collagen-induced platelet aggregation by nitroprusside. Br J Haematol 117, 664-675 (2002).

11. Radomski, M. W., Palmer, R. M. and Moncada, S. : Endogenous nitric oxide inhibits human platelet adhesion to vascular endothelium. Lancet 2, 1057-1058 (1987).

12. Liao, C. H., Tzeng, C. C. and Teng, C. M. : Cyclic AMP and cyclic GMP phosphodiesterase inhibition by an antiplatelet agent, 6-[(3-methylene-2-oxo-5-phenyl-5-tetrahydrofuranyl) methoxy)quinol inone (CCT-62). Eur J Pharmacol 349, 107114 (1998).

13. Yao, J., Zhu, Y., Sun, W., Sawada, N., Hiramatsu, N., Takeda, M. and Kitamura, M. : Irsogladine maleate potentiates the effects of nitric oxide on activation of cAMP signalling pathways and suppression of mesangial cell mitogenesis. $\mathrm{Br} \mathrm{J}$ Pharmacol. 151, 457-466 (2007).

14. Manns, J. M., Brenna, K. J., Colman, R. W. and Sheth, S. B. : Differential regulation of human platelet responses by cGMP inhibited and stimulated cAMP phosphodiesterases. Thromb Haemost. 87, 873-879 (2002).

15. Gibbins, J. M. : Platelet adhesion signalling and the regulation of thrombus formation. J Cell Sci 117, 3415-3425. (2004)

16. Rink, T. J., Sage, S. O.: Calcium signaling in human platelets. Annu Rev Physiol 52, 431-449 (1990).

17. Smith, J. B., Selak, M. A., Dangelmaier, C. and Daniel, J. L. : Cytosolic calcium as a second messenger for collageninduced platelet responses. Biochem J 288, 925-929 (1992).

18. Gillis, C. N. : Panax ginseng pharmacology: a nitric oxide link? Biochem Pharmacol 54, 1-8 (1997).

19. Attele, A. S., Wu, J. A. and Yuan, C. S. : Ginseng pharmacology: multiple constituents and multiple actions. Biochem Pharmacol 58, 1685-1693 (1999).

20. Park, H. J., Rhee, M. H., Park, K. M., Nam, K. Y. and Park, 
K. H. : Effect of non-saponin fraction from Panax ginseng on cGMP and thromboxane A2 in human platelet aggregation. J Ethnopharmacol. 49, 157-162 (1995).

21. Kim, E. H., Park, J. D., Pyo, S. N. and Rhee, D. K. : Effects of non-saponin red ginseng components on multi-drug resistance. J Ginseng Res 31, 74-78 (2007).

22. Kwak, Y. S., Shin, H. J., Song, Y. B., Kyung, J. S., Wee, J. J. and Park, J. D. : Effect of oral administration of red ginseng acidic polysaccharide on the tumor growth inhibition. J Ginseng Res 29, 176-181 (2005).

23. Park, K. M., Kim, Y. S., Jeong, T. C., Joe, C. O., Shin, H. J., Lee, Y. H., Nam, K. Y. and Park, J. D. : Nitric oxide is involved in the immunomodulating activities of acidic polysaccharide from Panax ginseng. Planta Med. 67, 122126 (2001).

24. Shin, H. J., Kim, Y. S., Kwak, Y. S., Song, Y. B., Kyung, J. S., Wee, J. J. and Park, J. D. : A further study on the inhibition of tumor growth and metastasis by red ginseng acidic polysaccharide (RGAP). Natural Product Sci 10, 284-288 (2004)

25. Lee, S. R., Park, J. H., Choi, K. J. and Kim, N. D. : Inhibitory effects of ginsenoside $\operatorname{Rg} 3$ on platelet aggregation and its mechanism of action. Korean J. Ginseng Sci. 21, 132-140 (1997).

26. Kim, S. D., Park, S. K., Cho, J. Y., Park, H. J., Lim, J. H., Yun, H. I., Park, S. C., Lee, K. Y., Kim, S. K. and Rhee, M. H. : Surfactin C inhibits platelet aggregation. J Pharm Pharmacol. 58, 867-870 (2006).

27. Laemmli, U. K. : Cleavage of structural proteins during the assembly of the head of bacteriophage T4. Nature 227, 680685 (1970).

28. Park, H. J., Rhee, M. H., Park, K. M., Nam, K. Y. and Park, K. H. : Effect of non-saponin fraction from Panax ginseng on cGMP and thromboxane A2 in human platelet aggregation. J Ethnopharmacol 49, 157-162 (1995).

29. Roberts, D. E., McNicol, A. and Bose, R. : Mechanism of collagen activation in human platelets. J Biol Chem 279, 19421-19430. Epub 12004 Feb 19423 (2004).
30. Farndale, R. W., Sixma, J. J., Barnes, M. J. and de Groot, P. G. : The role of collagen in thrombosis and hemostasis. $J$ Thromb Haemost 2, 561-573 (2004).

31. Holmsen, H. : Significance of testing platelet functions in vitro. Eur J Clin Invest 24, 3-8 (1994).

32. Daniel, J. L., Dangelmaier, C. A., Selak, M. and Smith, J. B. : ADP stimulates IP3 formation in human platelets. FEBS Lett 206, 299-303 (1986).

33. Rosado, J. A. and Sage, S. O.: The ERK cascade, a new pathway involved in the activation of store-mediated calcium entry in human platelets. Trends Cardiovasc Med 12, 229-234 (2002).

34. Borsch-Haubold, A. G., Kramer, R. M. and Watson, S. P. : Cytosolic phospholipase A2 is phosphorylated in collagenand thrombin-stimulated human platelets independent of protein kinase $\mathrm{C}$ and mitogen-activated protein kinase. $J$ Biol Chem 270, 25885-25892 (1995).

35. Mazharian, A., Roger, S., Maurice, P., Berrou, E., Popoff, M. R., Hoylaerts, M. F., Fauvel-Lafeve, F., Bonnefoy, A. and Bryckaert, M. : Differential Involvement of ERK2 and p38 in platelet adhesion to collagen. $J$ Biol Chem 280, 2600226010 (2005).

36. Roger, S., Pawlowski, M., Habib, A., Jandrot-Perrus, M., Rosa, J. P. and Bryckaert, M. : Costimulation of the Gi-coupled ADP receptor and the Gq-coupled TXA2 receptor is required for ERK2 activation in collagen-induced platelet aggregation. FEBS Lett 556, 227-235 (2004).

37. Rosado, J. A. and Sage, S. O. : Role of the ERK pathway in the activation of store-mediated calcium entry in human platelets. J Biol Chem 276, 15659-15665 (2001).

38. Garcia, A., Shankar, H., Murugappan, S., Kim, S. and Kunapuli, S. P. : Regulation and functional consequences of ADP receptor-mediated ERK2 activation in platelets. Biochem J. 404, 299-308 (2007).

39. McNicol, A. and Jackson, E. C. : Inhibition of the MEK/ ERK pathway has no effect on agonist-induced aggregation of human platelets. Biochem Pharmacol 65, 1243-1250 (2003). 